\title{
Rearing and Caring for a Future Xenograft Donor Pig
}

\author{
By Axel Kornerup Hansen, Kirsten Dahl and Dorte Bratbo Sørensen
}

Centre for Bioethics and Risk Assessment, Division of Laboratory Animal Science and Welfare, Department of Pharmacology and Pathobiology, Royal Veterinary and Agricultural University, DK-1870 Frederiksberg C, Denmark.

\section{Introduction}

Due to the shortage of human organs for allotransplantation, essential efforts aimed at developing a transgenic source animal (donor) for animal-human xenotransplantation have been performed over the last decade. Although man is concordant with old world primates, and the choice of this species would be an obvious way to prevent hyperacute rejection, there are several good reasons for preferring pigs to primates (Table 1). Therefore, concerns for future maintenance problems should be related to the pig. It can be questioned whether maintenance conditions of the transgenic xenograft donor pigs will differ significantly from non-transgenic pigs. Due to the fact that a xenograft donor pig is not yet fully available, little factual knowledge about this issue is available. However, in relation to a future xenograft donor pig basic and applied research has already created knowledge usable for the prediction of its health and welfare. Transgenic knock out mice partly equivalent to a future donor pig have existed for years, and basic knowledge on the function of the strategic transgenes is also available. Therefore, essential information on the impact of these modifications may be achieved by combining this information. Basically, these will be reared and cared for as for other pigs, but two considerations may make the maintenance principles different. Firstly, transgenesis may have induced new health and welfare problems in these pigs, and secondly, the specialized use of the pig may induce new hazards to the xenograft recipients and even to mankind, as such.

\section{Potential health and welfare problems of a future xeno-source pig}

Several types of gene-modified pigs aimed at avoiding complement activation against the al-

$\mathrm{T}$ a b 1 e 1 . Advantages and disadvantages choosing between pig and primates as xenograft source animals.

\begin{tabular}{lll}
\hline Characteristic & Primates & Pigs \\
\hline Hyperacute rejection & No & Yes \\
Breeding performance offspring/year/mother (app) & 1 & 20 \\
Knowledge on immunology and disease & Moderate & High \\
Risk of xenozoonotic infections & High & Moderate \\
Physiological compatibility & High & Moderate \\
Life span (years) & $10-15$ & $20-60$ \\
Size (kg) & $5-15$ & $10-300$ \\
\hline
\end{tabular}


pha-gal epitope have been produced, but so far, only three types seem to be have a realistic future as xenograft source animals:

1. Pigs with complement regulatory factors (CRF) inserted,

2. Pigs with a targeted mutation of the galactosyltransferase gene, so-called alpha-gal knock out pigs, and

3. The combination of 1 and 2 .

Both mice $(7,12,18,33)$ and pigs $(12,24)$ transgenic for CRF's have been produced, and within both species multiple transfection or crossbreeding have been used to produce double transgenic animals, either with two CRF's $(4,6)$ or one CRF and one alpha-gal related gene $(5,33)$. None of the papers report on any pathological, behavioural, clinical or otherwise welfare-related problems related to the pig carrying a human CRF. Animals transgenic for such genes will still express their own species specific CRF's, which will identify their organs as species-homologue, while the organ is placed in situ in the live xenograft source animal. Therefore, these transgenes are indeed less likely to cause problems for the xenograft donor, but closer examination of CRF transgenic animals are needed to state, whether, and to which extent, they are affected by the transgenesis.

Also alpha-gal knock out animals are available as both mice $(28,32)$ and pigs $(10,19)$. Dahl et al. (9) have listed four possible health and welfare consequences of this targeted mutation:

- Reduced sperm adhesion to zona pellucida.

- Increased sensibility to sepsis

- Increased sensibility to autoimmune diseases

- Cataract formation

Apart from these points, alpha-gal knock out animals seem to have the same size, appearance and clinical chemistry as their wild type litter mates, and their organs do not seem to differ macro- or microscopically $(28,31)$. After two years of observation of alpha-gal knock out mice in of one of the colonies the life span and health status seem to be normal (22). So, only little knowledge is available on health and welfare of alpha-gal knock out pigs, apart from the fact that they are viable.

\section{Reduced sperm adhesion to zona pellucida}

Gal transferases play an important role for the attachment of spermatozoa to zona pellucida $(26,27)$ by binding to $\mathrm{N}$-acetylglucosamine residues in the zona pellucida, while releasing alternative substrates that prevent the binding of other capacitated spermatozoa (25). It might, therefore, be expected that it would be difficult to produce homozygotic alpha-gal knock out animals, because the alpha-gal depleted sperm may not be able to bind to the zona pellucida and thus prevent further entry of other spermatozoa. Since two groups have reported the successful production of alpha-gal knock out mice $(28,32)$ these problems do not fully impair fertilisation, but one group reports that matings between heterozygous alpha-gal knock out carrier mice do not result in the expected 1:2:1 ratio (28). At least, it is, therefore, reasonable to assume that alpha-gal depleted spermatozoa are less competitive due to the lack of the gal transferase, although not fully incapable of fertilisation.

\section{Increased sensibility to sepsis}

Alpha-gal antibodies more frequently bind to Enterobacteriaceae isolates from patients with sepsis than to isolates from the stool of healthy humans (14). In these patients these antibodies do not seem to initiate complement-mediated lysis of alpha-gal epitope containing bacteria. Neither do they provide a protected site for $\mathrm{C} 3$ deposition. In the same way, bacteria isolated from the gallstones of patients with sepsis, have 
been shown to always express the a-gal epitope (34). These findings seem to indicate, that the alpha-gal antibodies are capable of protecting certain bacteria from complement-mediated lysis, and pigs with circulating alpha-gal antibodies may therefore express a higher degree of susceptibility to septicaemias caused by e.g. Escherichia coli.

\section{Increased sensibility to autoimmune diseases}

In human patients elevated titres of alpha-gal antibodies have been found in patients suffering from diseases with autoimmune elements, such as thyreoiditis. This could be due to the exposure of cryptic alpha-gal epitopes present in cells of certain tissues, e.g. thyroidea (11), or rearrangement and subsequent increased expression caused by binding of alpha-gal antibodies to the epitope on the cell surface (29), but it may also simply be an artefact caused by alpha-gal epitopes present on thyroid tissues used for bioassays (30). Elevated titers of alpha-gal antibodies have also been found in rheumatoid arthritis patients with kidney damage after treatment with gold and/or D-penicillamine (20).

\section{Cataract formation}

One of the two groups producing alpha-gal knock out mice reports that these animals develop cortical cataracts at the age of 4-6 weeks (28). Cataract formation is associated with significant membrane leakage, suggesting that the mouse lens is very sensitive to biochemical disturbance (22). No such changes are reported by the other group (32).

\section{Potential health and welfare problems of xenograft recipients}

Most concern about xenozoonotic infections is obviously related to the risk of activating porcine endogenous retroviruses (PERV) in the recipients, but it is unlikely that this risk can be dealt with in the production and maintenance process. However, it is clear that ordinary zoonotic infections known to be present in pigs, such as Salmonella sp., influenzaviruses, encephalymyocarditis virus and rotaviruses may compose a risk for the recipients. Furthermore, as pig production is of major economic impact in a number of countries, it is unacceptable to have human xenograft recipients as carriers of unwanted porcine infections. These are both problems to be solved in the production phase.

\section{Health protection in xenograft donor pigs}

The main problem in the production of xenograft source pigs to be dealt with in the production phase seems to be protection against infections. Protective systems with terms, such as Specific Pathogen Free (SPF) or Minimal Disease (MD), exist for pig production in many Western countries. Most of such regulations are aimed at improving agricultural economy rather than the more sophisticated use of the porcine organs for xenotransplantation. E.g. Danish SPF regulations ensure protection against Mycoplasma hyopneumoniae, Actinobacillus pleuropneumonia Type 2, Sarcoptes scabiei, Serpulina hyodysenteriae and toxinproducing Pasteurella multocida (1). Agents of interest in xenotransplantation, such as influenzaviruses and Erysipelothrix rhusiopathiae are common in these pig herds (2). Therefore, commercial laboratory pig producers as well as xenotransplantation research facilities generally follow even stricter regimes (16).

Pigs for upstart of breeding are produced by caesarian section or embryo transfer. Breeding and rearing is performed behind barriers that protect against unwanted infections. The staff needs to shower into the facility, redress in decontaminated clothes, and they are under strict quarantine if they have been in contact with other pigs. Diet, equipment and materials are decontaminated through autoclaves or chemi- 
cal locks, and the herd is currently screened for a high number of agents by a range of methods (17), e.g. as proposed for sentinel animals by the Federation of European Laboratory Animal Science Associations (23). Such regimes are under current development, as it may still prove difficult to remain free of any kind of porcine infection in countries where there is major production of pigs for agricultural purposes, and consequently inhabitants have massive contact with porcine products.

If alpha-gal antibodies are capable of protecting Enterobacteriaceae spp. from complementmediated lysis (14), this is very likely to become a problem in colonies of alpha-gal knock out pigs. Septicaemias caused by Enterobacteriaceae spp. are one of the most common causes of death in pig herds. It may occur in both piglets and young pigs (3) and as many as $2 \%$ of the population may die from this (8). E. coli is the most common cause, but also another alpha-gal epitope expressing bacterium, Klebsiella pneumoniae, is a common cause $(13,21)$. In the pig, all components of the native and the acquired immune systems develop in utero and are functional at birth, although less efficient (15). Therefore, lacking the ability to lyse septicaemic bacteria by complement may increase the incidence of septicaemias. If this is the case, this problem has to be dealt with in two ways. Either, the production systems must be changed to reduce factors, such as stocking densities and post-weaning stress compared to ordinary pig herds, or the pigs have to be bred in isolators, i.e. systems with no contact with the external environment or with humans which ensures full control of all infections. The latter will be time consuming and expensive.

\section{References}

1. Anonymous: Betingelser for deklareret kontrol med svinedysenteri; Betingelser for deklareret kontrol med skab; Betingelser for deklareret kontrol med ondartet lungesyge ( $\mathrm{Hp} 2)$; Betingelser for deklareret kontrol med smitsom nysesyge [Conditions for declared monitoring of porcine dysenteria; Conditions for declared monitoring of scabies; Conditions for declared monitoring of evil lung disease ( $\mathrm{Hp} 2)$; Conditions for declared monitoring of infectious cough]. 1987. Copenhagen, Danske Slagterier [Danish Meathouse Organisation].

2. Anonymous: Annual Report. Frederiksberg, National Veterinary Laboratory \& State Institute for Virus Research, 2001.

3. Bertschinger HU, Fairborther JM: Eschericia coli infections. In: Diseases of swine. (Eds.Straw B, D'Allaire S, Mengeling WL, Taylor DJ). Oxford: Blackwell Science 1999, 8, 431-468.

4. Byrne GW, McCurry KR, Martin MJ, McClellan SM, Platt JL, Logan JS: Transgenic pigs expressing human CD59 and decay-accelerating factor produce an intrinsic barrier to complement-mediated damage. Transplantation 1997, 63, 149-155.

5. Costa C, Zhao L, Burton WV, Rosas C, Bondioli KR, Williams BL, Hoagland TA, Dalmasso AP, Fodor WL: Transgenic pigs designed to express human CD59 and H- transferase to avoid humoral xenograft rejection. Xenotransplantation 2002, 9, 45-57.

6. Cowan PJ, Shinkel TA, Aminian A, Romanella M, Wigley PL, Lonie AJ, Nottle MB, Pearse MJ, d'Apice AJF: High-level co-expression of complement regulators on vascular endothelium in transgenic mice: CD55 and CD59 provide greater protection from human complement-mediated injury than CD59 alone. Xenotransplantation 1998, 5, 184-190.

7. Cowan PJ, Shinkel TA, Witort EJ, Barlow H, Pearse MJ, d'Apice AJ: Targeting gene expression to endothelial cells in transgenic mice using the human intercellular adhesion molecule 2 promoter. Transplantation 1996, 62, 155-160.

8. Cutler RS, Fahy VA, Spicer EM, Cronin GM: Preweaning Mortality. In: Diseases of swine. (Eds.Straw B, D'Allaire S, Mengeling WL, Taylor DJ). Oxford: Blackwell Science 1999, 8, 9851001.

9. Dahl K, Sandøe P, Johnsen PF, Lassen J, Hansen $A K$ : Outline of a risk assessment: Welfare of a 
future xenotransplantation donor pig. Anim Welf 2003 (In Press).

10. Dai YF, Vaught TD, Boone J, Chen SH, Phelps CJ, Ball S, Monahan JA, Jobst PM, McCreath KJ, Lamborn AE, Cowell-Lucero JL, Wells KD, Colman A, Polejaeva IA, Ayares DL: Targeted disruption of the alpha 1,3-galactosyltransferase gene in cloned pigs. Nature Biotechn 2002, 20, 251-255.

11. Etienne-Decerf J, Malaise M, Mahieu P, Winand $R$ : Elevated anti-alpha-galactosyl antibody titres. A marker of progression in autoimmune thyroid disorders and in endocrine ophthalmopathy? Acta Endocrinol (Copenh) 1987, 115, 67-74.

12. Fodor WL, Williams BL, Matis LA, Madri JA, Rollins SA, Knight JW, Velander W, Squinto SP: Expression of a functional human complement inhibitor in a transgenic pig as a model for the prevention of xenogeneic hyperacute organ rejection. Proc Natl Acad Sci U S A 1994, 91, 11153-11157.

13. Glastonbury JRW: A survey of preweaning mortality in the pig. Austral Vet J1 1976, 52, 272-276.

14. Hamadeh RM, Jarvis GA, Galili U, Mandrell RE, Zhou P, Griffiss JM: Human natural anti-Gal IgG regulates alternative complement pathway activation on bacterial surfaces. J Clin Invest 1992, 89, 1223-1235.

15. Hammerberg $C$, Schurig $G G$, Ochs DL: Immunodeficiency in young pigs. Am J Vet Res 1989, 50, 868-874.

16. Hansen $A K$ : Microbiological quality of laboratory pigs. Scand J Lab Anim Sci 1998, 25, $145-$ 152.

17. Hansen AK, Farlov H, Bollen P: Microbiological monitoring of laboratory pigs. Lab Anim 1997, 31, 193-200.

18. Ijzermans J, Schraa EO, Bonthuis F, Yannnoutsos $N$, Marquet $R L$ : In vivo evaluation of human membrane cofactor protein in transgenic mice. Transplant Proc 1996, 28, 671-672.

19. Lai LX, Kolber-Simonds D, Park KW, Cheong HT, Greenstein JL, Im GS, Samuel M, Bonk A, Rieke A, Day BN, Murphy CN, Carter DB, Hawley RJ, Prather RS: Production of alpha-1,3-galactosyltransferase knockout pigs by nuclear transfer coning. Science 2002, 295, 1089-1092.

20. Malaise MG, Davin JC, Mahieu PR, Franchimont $P$ : Elevated antigalactosyl antibody titers reflect renal injury after gold or D-penicillamine in rheumatoid arthritis [published erratum appears in Clin Immunol Immunopathol 1986 Nov;
41(2):303]. Clin Immunol Immunopathol 1986, 40, 356-364.

21. Nielsen NC, Riising HJ, Larsen JL, Bille N, Svendsen J: Preweaning mortality in pigs: Acute septicaemias. Nordisk Veterinærmedicin 1975, 27, 129-139.

22. Pearse MJ, Cowan PJ, Shinkel TA, Chen CG, d'Apice AJF: Anti-Xenograft Immune Responses in alpha-1,3-Galactosyltransferase KnockOut Mice. In: alpha-Gal and Anti-Gal. (Eds. Galili U, Avila JL). New York: Kluwer Academic/Plenum Publishers 1999, 281-310.

23. Rehbinder C, Baneux P, Forbes D, van Herck $H$, Nicklas $W$, Rugaya $Z$, Winkler $G$ : FELASA recommendations for the health monitoring of breeding colonies and experimental units of cats, dogs and pigs - Report of the Federation of European Laboratory Animal Science Associations (FELASA) Working Group on Animal Health. Lab Anim 1998, 32, 1-17.

24. Rosengard AM, Cary NRB, Langford GA, Tucker $A W$, Wallwork J, White DJG: Tissue Expression of Human-Complement Inhibitor, Decay- Accelerating Factor, in Transgenic Pigs - A Potential Approach for Preventing Xenograft Rejection. Transplantation 1995, 59, 1325-1333.

25. Shapiro BM, Eddy EM: When sperm meets egg: biochemical mechanisms of gamete interaction. Int Rev Cytol 1980, 66, 257-302.

26. Shur BD, Hall NG: A role for mouse sperm surface galactosyltransferase in sperm binding to the egg zona pellucida. J Cell Biol 1982, 95, 574579.

27. Shur BD, Hall NG: Sperm surface galactosyltransferase activities during in vitro capacitation. J Cell Biol 1982, 95, 567-573.

28. Tearle RG, Tange MJ, Zannettino ZL, Katerelos $M$, Shinkel TA, vanDenderen BJW, Lonie AJ, Lyons I, Nottle MB, Cox T, Becker C, Peura AM, Wigley PL, Crawford RJ, Robins AJ, Pearse MJ, DApice AJF: The alpha-1,3-galactosyltransferase knockout mouse - Implications for xenotransplantation. Transplantation 1996, 61, 13-19.

29. Thall A, Etienne-Decerf J, Winand RJ, Galili U: The alpha-galactosyl epitope on human normal and autoimmune thyroid cells. Autoimmunity 1991, 10, 81-87.

30. Thall A, Etienne-Decerf J, Winand RJ, Galili U: The alpha-galactosyl epitope on mammalian thyroid cells. Acta Endocrinol (Copenh) 1991, 124, 692-699.

31. Thall A, Etiennedecerf J, Winand RJ, Galili U: 
The Alpha-Galactosyl Epitope on Mammalian Thyroid-Cells. Acta Endocrinol 1991, 124, 692699.

32. Thall AD, Maly P, Lowe JB: Oocyte Gal-Alpha1,3gal Epitopes Implicated In Sperm Adhesion to The Zona-Pellucida Glycoprotein Zp3 Are Not Required for Fertilization in the Mouse. J Biol Chem 1995, 270, 21437-21440.

33. van Denderen BJW, Salvaris E, Romanella $M$, Aminian A, Katerelos M, Tange MJ, Pearse MJ,
DApice AJF: Combination of decay-accelerating factor expression and alpha 1,3-galactosyltransferase knockout affords added protection from human complement-mediated injury. Transplantation 1997, 64, 882-888.

34. Wetter LA, Hamadeh RM, Griffiss JM, Oesterle A, Aagaard B, Way LW: Differences in outer membrane characteristics between gallstone-associated bacteria and normal bacterial flora. Lancet 1994, 343, 444-448. 